\title{
A Case of Pediatric Follicular Lymphoma in the Parotid Gland
}

\author{
Hee Ryung Kim ${ }^{1}$, Jae Young Jeong ${ }^{1}$, Ye Seul Kim², and Kyung Tae ${ }^{1}$ (D) \\ ${ }^{1}$ Departments of Otolaryngology-Head and Neck Surgery, ${ }^{2}$ Pathology, College of Medicine, Hanyang University, Seoul, Korea
}

\section{이하선의 소아형 여포성 림프종 1예}

김희령 ${ }^{1} \cdot$ 정재영 $^{1} \cdot$ 김예슬 $^{2} \cdot$ 태 경 $^{1}$

한양대학교 의과대학 이비인후-두경부외과학교실, ${ }^{1}$ 병리학교실 ${ }^{2}$

\author{
Received May 17, 2020 \\ Revised August 3,2020 \\ Accepted August 13, 2020 \\ Address for correspondence \\ Kyung Tae, MD, PhD \\ Department of Otolaryngology- \\ Head and Neck Surgery, \\ College of Medicine, \\ Hanyang University, \\ 222 Wangsimni-ro, Seongdong-gu, \\ Seoul 04763 , Korea \\ Tel $+82-2-2290-8585$ \\ Fax +82-2-2293-3335 \\ E-mail kytae@hanyang.ac.kr
}

Pediatric follicular lymphoma (PFL) is rare, and it has distinctive characteristics compared to adult-type follicular lymphoma. PFL mainly occurs in males and is likely to be localized to cervical lymph nodes and tonsils. Extranodal type PFL also occurs in the testis, epididymis, skin, gastrointestinal tract, and parotid gland, etc. The prognosis of PFL is better than adulttype follicular lymphoma. Surgical excision is a good option, and the majority of PFL cases show complete remission after surgery. We have encountered a case of PFL of the parotid gland in a 12-year-old boy. Here, we report this case with a review of the literature.

Korean J Otorhinolaryngol-Head Neck Surg 2021;64(6):439-43

Key Words Lymphoma Parotid gland · Pediatric follicular lymphoma.

\section{서 론}

타액선에 발생하는 악성 종양은 매우 드물며, 주로 이하선 에서 발생한다. 이하선의 악성 종양은 점액표피세포암 $(\mathrm{mu}-$ coepidermoid carcinoma), 포도상선세포암종(acinic cell carcinoma), 선낭암종(adenoid cystic carcinoma), 다형선암 종(carcinoma in pleomorphic adenoma), 림프종 등이 있다. 특히 이하선 림프종은 매우 드물어, 전체 이하선 종양의 약 $0.6 \sim 5 \%$, 모든 원발성 절외 악성 림프종의 약 5\% 미만을 차 지하며, 전체 비호지킨 림프종의 $0.87 \%$ 를 차지한다. ${ }^{1)}$ 이하선 은 발생학상 림프조직 형성 이후 피막이 생기기 때문에 이하 선 내부나 이하선 주변의 림프절에 이하선 실질 조직과 침샘 관의 상피 조직이 남게되며, 따라서 이하선 림프종은 이하선

This is an Open Access article distributed under the terms of the Creative Common Attribution Non-Commercial License (https://creativecommons.org/licenses/by-nc/4.0) which permits unrestricted non-commercial use, distribution, and reproduction in any medium, provided the original work is properly cited.
주변 림프절이나 이하선 실질 내부의 림프조직에서 발생할 수 있다. ${ }^{2}$ 이하선의 림프종의 가장 흔한 조직학적 아형은 mucosa-associated lymphoid tissue(MALT) 림프종(lymphoma)이며, 그외, 미만성 B형 대세포 림프종(diffuse large $\mathrm{B}$ cell lymphoma), 여포성 림프종(follicular lymphoma, FL) 등이 발생한다. 드물게, 이하선의 림프양 조직에서 발생한 와 르틴 종양의 약 $1 \%$ 미만에서 악성화되어 림프종이 발생할 수 있다. ${ }^{3)}$

비호지킨 림프종에 속하는 여포성 림프종(FL)은 B 림프구 기원의 림프종으로 주로 60 대 남성에서 호발하며 서양인에 게서 흔히 발생하며 동양인에서는 드물다. 소아 및 청소년에 서 발병하는 소아형 여포성 림프종(pediatric follicular lymphoma)은 극히 드물며, 여포성 림프종의 아형으로 2008 World Health Organization 혈액종양 진단 기준에서 여포 성 림프종의 하위 그룹으로 새로이 분류되었다. ${ }^{4}$ 소아형 여 포성 림프종은 소아 림프종의 $6.5 \%$ 미만이며, 특히 소아형 
비호지킨 림프종 중에서는 1 2\% 미만인 아주 드문 여포성 림프종의 변형이다. ${ }^{5}$ 소아형 여포성 림프종은 주로 경부 림 프절이나 편도에서 발생하며, 이하선에서 발생하는 경우는 극히 드물다. ${ }^{5,6}$

저자들은 1 달간 서서히 자라난 무통성의 이하선 종물을 주소로 내원한 12세 남자 환자에서 발생한 소아형 여포성 림 프종을 경험하였기에 문헌 고찰과 함께 증례를 보고하고자 한다.

\section{증 례}

12 세 남아가 내원 1 개월 전부터 촉지된 우측 이개 하방 부 위의 무통성 종물을 주소로 내원하였다. 발열, 인후통 등의

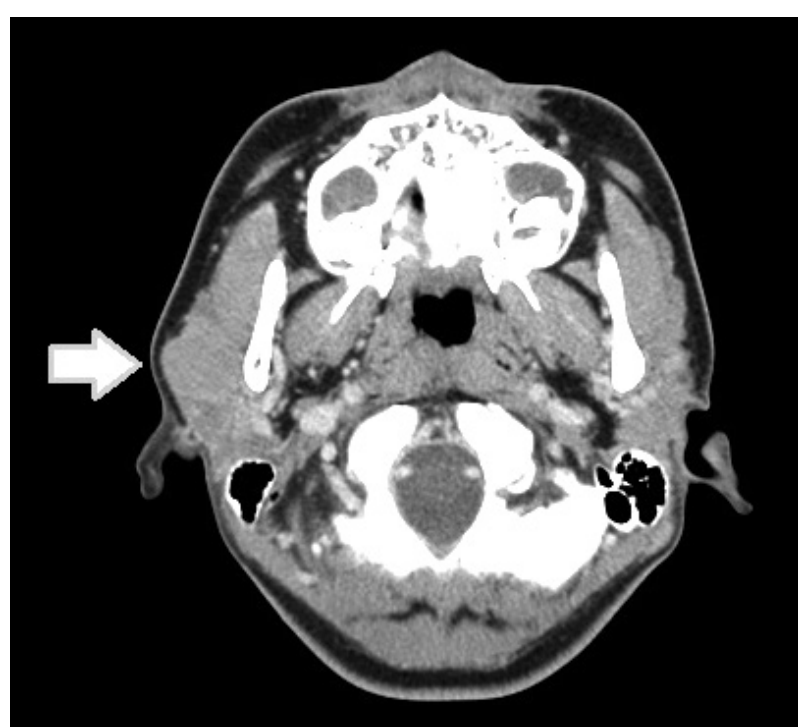

Fig. 1. CT scan with contrast enhancement shows a $2.2 \times 2.2 \times 3.6$ $\mathrm{cm}$ sized mass (arrow) in the superficial lobe of the right parotid gland with mild enhancement.
증상은 동반되지 않았고, 야간 발한, 체중 감소 등의 전신 증 상도 없었다. 환자의 과거력 및 가족력상 특이 소견은 없었다. 신체검사상 우측 이하선에 약 $3 \mathrm{~cm}$ 크기의 종괴가 촉진되었 으며, 통증과 압통은 없었다.

경부 전산화단층촬영상, 우측 이하선 천엽에 $2.2 \times 2.2 \times 3.6$ $\mathrm{cm}$ 크기의 종물이 있었으며, 종물은 둥근 형태를 띄며 가장 자리가 조영 증강을 보이며 내부로는 균일하고 경계는 분명 하였다(Fig. 1), 경부 초음파상 $1.7 \times 2.0 \times 1.4 \mathrm{~cm}$ 의 내부 혈류 를 동반한 저음영의 종물 소견을 보였으며, 초음파하 세침 흡 인 세포 검사를 시행하였다. 세포병리 결과상 비정형 림프 세 포만 있어 확진에는 불충분한 소견을 보였다. 종양의 치료와 병리 진단을 위해 수술을 하기로 하였으며, 술전 혈액 검사를 포함하여 다른 검사상 이상 소견은 없었다.

수술은 modified facelift 절개하에 종물을 en-bloc으로 절제하기 위해 종물 주위에 정상 이하선조직을 포함한 이하 선 천엽 부분 절제술을 시행하였다. 종물은 $3.5 \times 2.2 \mathrm{~cm}$ 크 기로 이하선 천엽에 위치하였으며 주변 조직이나 안면신경의 침범은 없었다(Fig. 2). 수술 중 안면신경 감시를 시행하며 안 면 신경의 손상 없이 종물을 절제하였으며, 동결 절편 검사상 림프조직에서 기원한 병변으로 반응성 림프절염이나 림프종 의심하에 수술을 종결하였다. 수술 후 안면신경 마비나 다른 합병증은 없었다.

최종 병리 검사 결과 이하선 내 림프조직에서 발생한 소아 형 여포성 림프종으로 진단되었다. 육안적으로 종괴는 $3 \times 2.7$ $\times 2 \mathrm{~cm}$ 크기 였으며, 무게는 $7 \mathrm{~g}$ 으로 탄성을 지닌 경계가 불 분명한 회백색의 단면이 관찰되었다. 저배율 현미경 검사상 여포는 사행성(serpinginous)의 성장 양상을 보였으며, 고배 율에서는 단형성(monomorphic)의 아구성(blastoid)의 세포 증식을 보였다(Fig. 3). 면역조직화학 검사에서 B 림프구의 표 지자인 CD20에 양성 소견을 보였고 여포의 표지자인 CD10
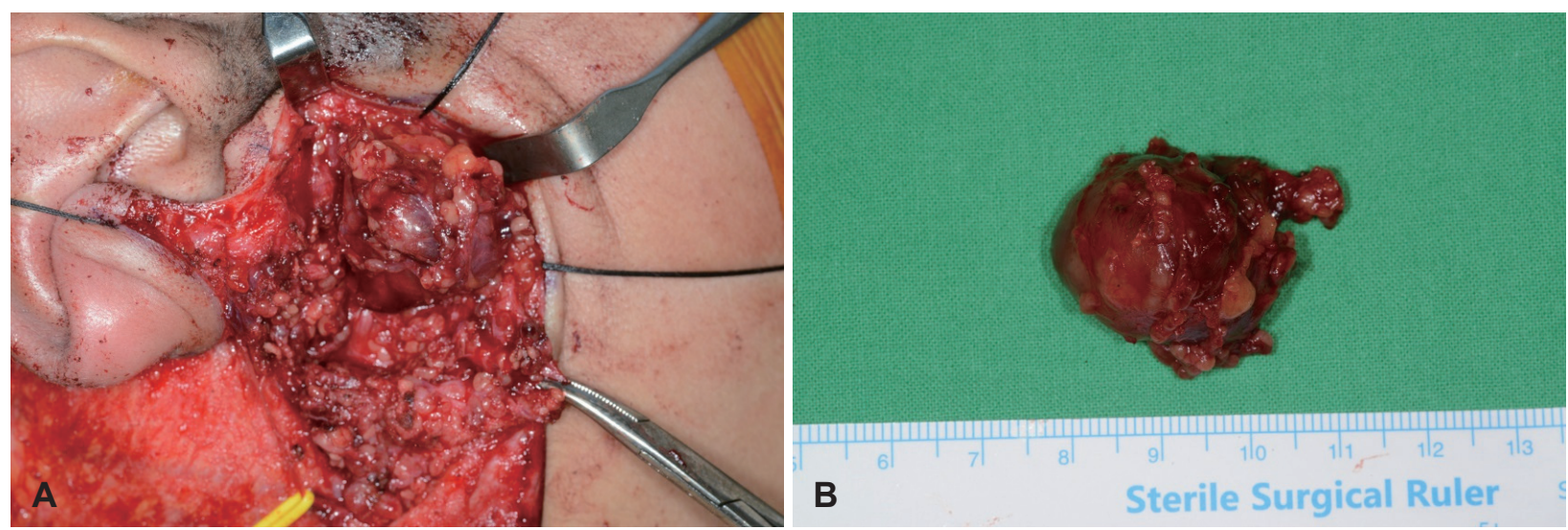

Fig. 2. Surgical findings. The operative view showing a mass at the superficial lobe of the parotid gland (A). Surgical specimen $3.5 \times 2.2$ $\mathrm{cm}$ in size $(\mathrm{B})$. 
에도 양성이었으며, 성인 여포성 림프종과 감별할 수 있는 Bcell lymphoma 2(Bcl-2)에서는 음성 소견을 보였다(Fig. 4).

수술 후 소아형 여포성 림프종 진단하에 병기 설정을 위해
타원에서 골수 생검과 양전자방출 컴퓨터단층촬영을 시행하 였다. 골수 생검상 특이 이상 소견은 없었으며, 양전자방출 컴 퓨터단층촬영상 우측 비인두에 섭취 증가 소견 관찰되어 시
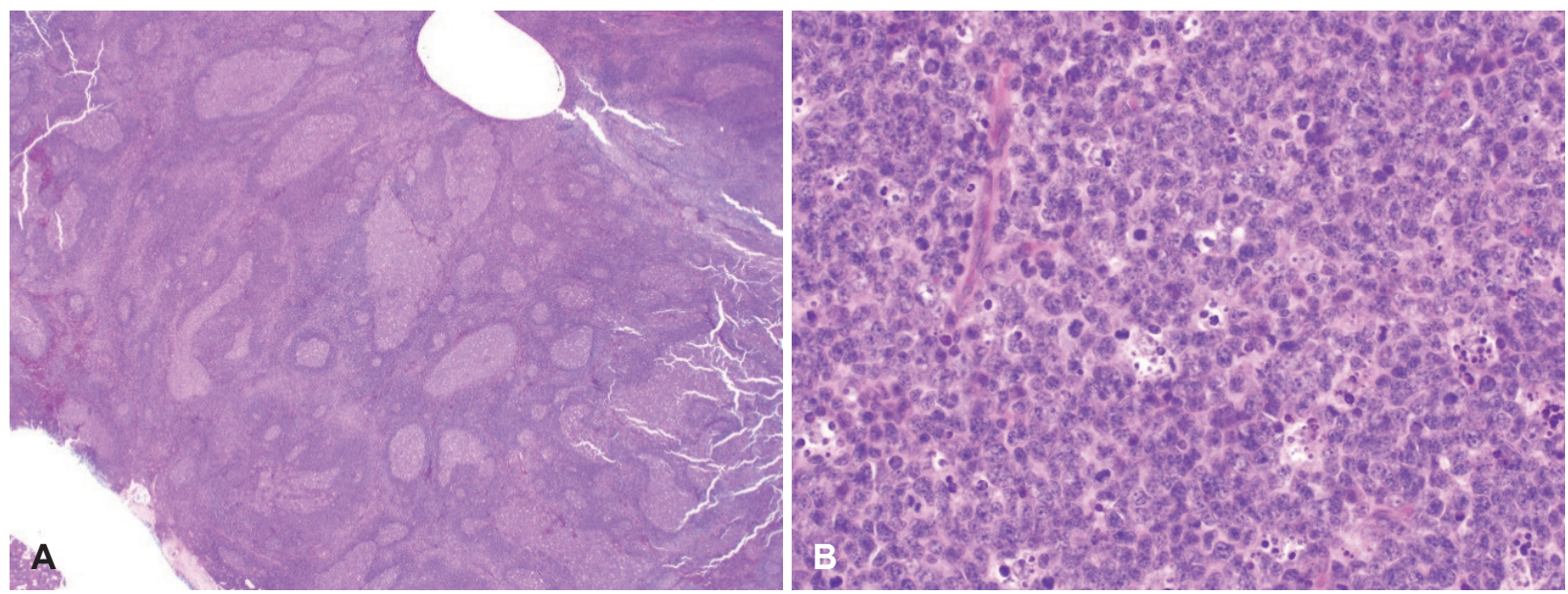

Fig. 3. Pathologic findings. Low-magnification $(H \& E$ stain, $\times 2.5)$ view shows serpiginous follicles $(A)$. High magnification $(H \& E$ stain, $\times 400$ ) demonstrates the typical cytomorphologic features of neoplastic cells with prominent blastoid pattern (B). H\&E: hematoxylin and eosin.
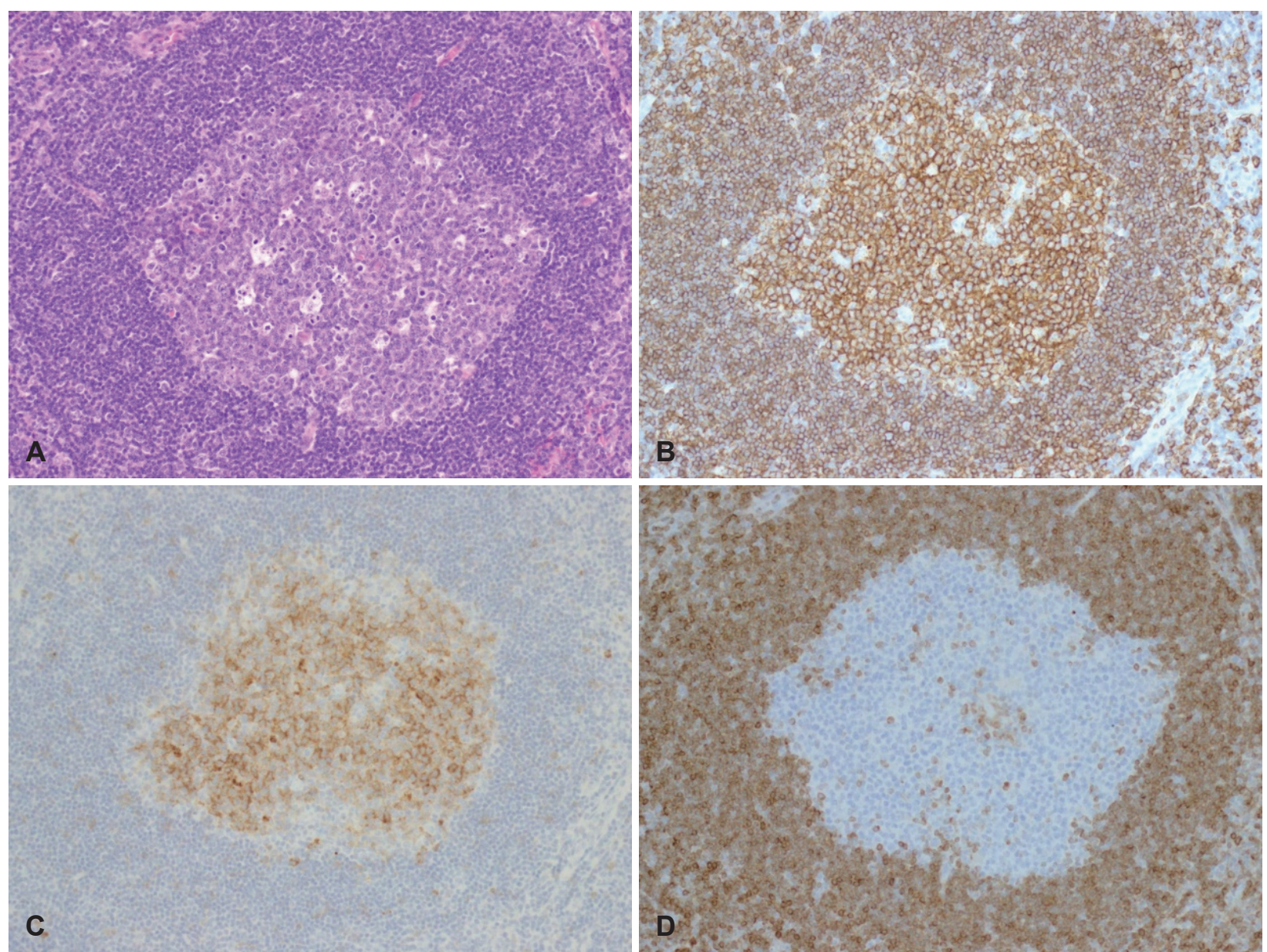

Fig. 4. Immunohistochemical staining. Hematoxylin and eosin stain of follicle shows a starry-sky pattern $(\times 200)(A)$. Positive immunostaining for CD20 in follicular center cells and many interfollicular cells $(\times 200)(B)$. Positive immunostaining for CD10 $(\times 200)(C)$. Negative immunostaining for B cell lymphoma 2 in the follicular area $(\times 200)(D)$. 
행한 조직 검사상 만성 염증 소견을 보였다.

환자는 수술 후 추가적 치료 없이 경과 관찰 중이며 술후 11 개월인 현재까지 재발 소견은 없다.

\section{고 찰}

여포성 림프종(FL)은 B 림프구에서 기원하며, 모든 비호 지킨 림프종의 약 $35 \%$ 를 차지한다. 여포성 림프종의 임상 양 상은 매우 다양한데, 무통성의 미만성 림프절 병증이 호전과 악화를 반복하는 것을 주 증상으로 하며, B 증상이 $20 \%$ 이 하에서 나타나고, serum lactate dehydrogenase의 증가도 $20 \%$ 이하에서만 나타난다. ${ }^{4)}$

소아 및 청소년 연령층에서 발생하는 소아형 여포성 림프 종은 주로 남아에서 호발하며, 평균 연령은 약 11 세이다. ${ }^{5,6)}$ 주로 경부 림프절 또는 편도에 발생하며, 절외 병소로는 고환 에서 가장 호발한다. 성인형과 소아형의 명확한 조직학적 및 분자생물학적 차이는 없으나, 소아형은 성인형에서와 달리 약 $80 \%$ 에서만 $\mathrm{CD} 10$ 이 발현되며, 성인형에서 특징적으로 나 타나는 Bcl-2단백의 발현과 유전자 translocation t(14;18)의 빈도가 드문 것으로 알려져 있다. ${ }^{6-9)}$

성인형과 소아형 여포성 림프종의 병의 진행과 예후에 있어 중요한 차이점이 있는데, 성인에서 발생하는 여포성 림프종은 진행이 매우 느리지만 절외 림프절 침범이 흔하며, 확진 당시 진행된 병기로 발견되는 경우가 많다. 또한 재발이 흔하게 발 생하며 재발 후 더욱 공격적인 양상으로 진행하기 때문에 완 치가 어려운 질환이다. ${ }^{410)}$ 초기 병기로 발견되는 경우는 약 $10 \%$ 정도이며, 주로 국소적 방사선 치료가 권고되며, 수술은 국소에 국한된 병변이나 진단을 위하여 제한적으로 시행된 다. 초기 병기의 환자에서 수술 후 추가적인 항암 화학요법을 병행하는 것이 완전 관해에 도움이 된다는 보고가 있으며, 초기 림프종 중 위험도가 낮고 무증상을 보이는 몇몇 선택적 인 환자에서는 치료 없이 경과 관찰할 수 있다.' 진행된 병기 에서는 통상적으로 항암 화학요법과 표적치료제(rituximab) 가 사용되며, 완전 관해 10년 후의 재발률이 $50 \%$ 이상으로, 관해율은 높으나 다시 재발하는 비율이 높아 병의 완치율은 높지 않다. ${ }^{11}$

소아형 여포성 림프종은 발생 빈도가 적어 아직 명확한 치 료 권고안이 정립되지는 않았지만, 보고된 증례들을 바탕으 로 하였을 때, 발견 당시 병기가 낮은 경우가 많아서 5년 생 존율이 $95 \%$ 이상으로 비교적 좋은 예후를 보인다. ${ }^{8)}$ 소아형 여포성 림프종 Stage I 또는 II의 초기 병기의 경우 원발 병 소가 국소부위에 국한되어 있어 수술적 절제만으로 완전 관 해가 가능하다. 따라서 성인형 여포성 림프종에서의 치료와
달리 술후 항암화학요법 또는 방사선 치료를 추가로 시행하 는 것은 환아에게 미치는 전신 합병증 및 치료의 독성을 고 려하였을 때 주로 권고되지 않는다. ${ }^{9-13}$

이하선의 림프 조직에서 원발한 소아형 여포성 림프종 환 자는 대부분 무통성의 이하선 종물을 주소로 내원하여 다른 이하선 종물과의 감별진단이 어렵다. 특히 술전 경부 전산화 단층촬영에서 림프절 또는 림프조직의 비대를 동반한 균질 한 조영 증강을 보이고, 초음파 검사상 저에코 음영의 종물 소견을 보이나 림프종을 진단할 수 있는 특이 소견은 없으며, 미세침 흡인 생검에서도 비정형적 림프조직 소견만으로는 원 발성 림프종을 진단하기는 어렵기 때문에, 최종 진단은 수술 후에 내려지는 경우가 많다. ${ }^{14)}$

수술은 병변이 이하선 정상 실질 주변부까지 침윤되는 양 상을 보이기 때문에 종물의 단순 절제보다는 종물을 포함한 en-bloc 절제를 위한 이하선 천엽 절제술을 시행하는 것이 원칙이다. 이하선의 소아형 여포성 림프종의 경우 일차 병변 부위에 국한된 경우가 대부분이기 때문에 수술을 통한 원발 병변의 제거만으로도 완전 관해가 가능하며 소아형의 경우 재발률이 낮아 수술적 치료만으로도 예후는 좋은 것으로 알 려져 있다. ${ }^{15)}$

결론적으로, 본 증례는 소아에서 발생한 무통성 이하선 종 물의 경우 술전 검사상 진단이 불충분한 경우가 많기 때문에 드물지만 소아형 여포성 림프종의 가능성을 염두에 두고 감 별하여야 한다는 점에서 주목할만한 증례이며, 이하선에서 발생한 소아형 여포성 림프종의 경우 수술을 통해 질환의 확 진과 더불어 완전 관해를 얻을 수 있음을 보여주는 증례로 사료된다.

\section{Acknowledgments}

None.

\section{Author Contribution}

Conceptualization: Kyung Tae. Data curation: Hee Ryung Kim, Ye Seul Kim. Formal analysis: Hee Ryung Kim, Jae Young Jeong. Methodology: Hee Ryung Kim, Ye Seul Kim, Kyung Tae. Supervision: Kyung Tae. Writing — original draft: Hee Ryung Kim. Writing — review \& editing: Kyung Tae, Jae Young Jeong, Ye Seul Kim.

\section{ORCID}

Kyung Tae

https://orcid.org/0000-0002-0382-2072

\section{REFERENCES}

1) Nassie DI, Berkowitz M, Wolf M, Kronenberg J, Talmi YP. Parotid mass as presenting symptom of lymphoma. Isr Med Assoc J 2010; 12(7):416-8.

2) Batsakis JG, el-Naggar AK. Warthin's tumor. Ann Otol Rhinol Laryngol 1990;99(7 Pt 1):588-91.

3) Alnoor F, Gandhi JS, Stein MK, Gradowski JF. Follicular lymphoma diagnosed in warthin tumor: A case report and review 
of the literature. Head Neck Pathol 2020;14(2):386-91.

4) Freedman A. Follicular lymphoma: 2018 update on diagnosis and management. Am J Hematol 2018;93(2):296-305.

5) Oschlies I, Salaverria I, Mahn F, Meinhardt A, Zimmermann M, Woessmann W, et al. Pediatric follicular lymphoma--a clinicopathological study of a population-based series of patients treated within the Non-Hodgkin's Lymphoma--Berlin-Frankfurt-Munster (NHL-BFM) multicenter trials. Haematologica 2010;95(2):253-9.

6) Lorsbach RB, Shay-Seymore D, Moore J, Banks PM, Hasserjian RP, Sandlund JT, et al. Clinicopathologic analysis of follicular lymphoma occurring in children. Blood 2002;99(6):1959-64.

7) Louissaint A Jr, Ackerman AM, Dias-Santagata D, Ferry JA, Hochberg EP, Huang MS, et al. Pediatric-type nodal follicular lymphoma: An indolent clonal proliferation in children and adults with high proliferation index and no BCL2 rearrangement. Blood 2012;120(12):2395-404.

8) Koo M, Ohgami RS. Pediatric-type follicular lymphoma and pediatric nodal marginal zone lymphoma: Recent clinical, morphologic, immunophenotypic, and genetic insights. Adv Anat Pathol 2017;24(3):128-35.

9) Liu Q, Salaverria I, Pittaluga S, Jegalian AG, Xi L, Siebert R, et al. Follicular lymphomas in children and young adults: A comparison of the pediatric variant with usual follicular lymphoma. Am J Surg Pathol 2013;37(3):333-43.

10) Agrawal R, Wang J. Pediatric follicular lymphoma: A rare clinicopathologic entity. Arch Pathol Lab Med 2009;133(1):142-6.

11) Friedberg JW, Byrtek M, Link BK, Flowers C, Taylor M, Hainsworth $\mathrm{J}$, et al. Effectiveness of first-line management strategies for stage I follicular lymphoma: Analysis of the National LymphoCare Study. J Clin Oncol 2012;30(27):3368-75.

12) Kumar R, Galardy PJ, Dogan A, Rodriguez V, Khan SP. Rituximab in combination with multiagent chemotherapy for pediatric follicular lymphoma. Pediatr Blood Cancer 2011;57(2):317-20.

13) Swerdlow SH, Campo E, Pileri SA, Harris NL, Stein H, Siebert R, et al. The 2016 revision of the World Health Organization classification of lymphoid neoplasms. Blood 2016;127(20):2375-90.

14) Lennon P, Silvera VM, Perez-Atayde A, Cunningham MJ, Rahbar R. Disorders and tumors of the salivary glands in children. Otolaryngol Clin North Am 2015;48(1):153-73.

15) Attarbaschi A, Beishuizen A, Mann G, Rosolen A, Mori T, Uyttebroeck A, et al. Children and adolescents with follicular lymphoma have an excellent prognosis with either limited chemotherapy or with a "watch and wait" strategy after complete resection. Ann Hematol 2013;92(11):1537-41. 